\title{
Instilling Islamic Values in Foreign Language Teaching: An Indonesian Context
}

\author{
Ahmad Madkura, Azkia Muharom Albantani ${ }^{\mathrm{b}}$ \\ ${ }^{a}$ State Institute for Islamic Studies (IAIN) Metro, J1. Ki Hajar Dewantara 34112 No.15A, Lampung, Indonesia \\ ${ }^{\text {b }}$ Syarif Hidayatullah State Islamic University Jakarta, Jl. Ir. H. Juanda 15412 No. 95, Jakarta, Indonesia \\ Corresponding e-mail: madzkurahmad@metrouniv.ac.id
}

\begin{abstract}
Recently, there seem a significantly growing number of studies in the relationship of religion and instructional activities. In Indonesia, the world's biggest Muslim country where the big number of Islamaffiliated schools play a role in shaping the educational policy, it is considered important that teachers find a good way to take a part in delivering Islamic values while administering the instruction, particularly in the teaching of a foreign language. However, it is still found hard to find the practical and effective strategies to implement both. Moreover, not all experts say yes to include religious teachings and language pedagogy. This paper is aimed at comprehensively discussing the importance and the practices of instilling Islamic values in foreign language classroom in Indonesian context. By doing this, it is expected that the Muslim learners could both achieve the foreign language skills and, in the same time, become more aware of filtering the culture, which is irrelevant with theirs, contained in foreign language they are learning.
\end{abstract}

Keywords: Islamic values, foreign language teaching, instilling

\section{INTRODUCTION}

The success of communication in second or foreign language is indicated by at least two aspects, communicative aspect (Bagarić, 2007; Mecham, 2012) and intercultural aspect (Atay, et al, 2009; Mitchell, et al, 2015). The second aspect requires the learners to have cultural insight $(\mathrm{Qu}, 2010$; Wahyudi, 2012) that should be taught in the targeted language teaching. This statement is in line with what Buttjes (1990) emphasizes that language teaching is culture teaching. Therefore, language teachers must pay a big attention to the learners' cultural background.

One of the learners' most important backgrounds is the religion because it shapes human' behavior (Kilp, 2011; Sasaki \& Kim, 2011; Aldashev \& Platteau, 2014). Studies on the relationship of the religion and pedagogy have been widely conducted. Johnston (2003) and Wicking (2012) argue that the teaching process and interactions at schools is influenced by the teacher's moral and religious viewpoint, while Purgason (2009) suggests that it is fine for the language teachers to let religion or any other contentious issue appear in the classroom. Shahjahan's study $(2004,2010)$ has offered a hopeful lane for embracing spirituality, not only Christianity, into education in general and language teaching in non-Western settings possibly accomplished by local teachers and students. Meaning to say, Shahjahan argued that all religions are possible to be incorporated into the teaching of all subjects.

Strengthening this statement, Foye (2004) concluded that as long as the language materials are successfully taught, putting religious values in the instruction is no problem. Also, Liyanage, Bartlett, and Grimbeek (2010) hold the sight that one of the factors necessary to be involved in learning design is their ethno-religious backgrounds.

In Indonesia, there are five officially admitted religions namely Islam, Christianity, Hinduism, Buddhism and Confucianism. Among those religion, Islam has the largest adherents. The big number of 
Muslims in Indonesia makes it the world's biggest Muslim population. Therefore, Islam influences many fields such as economics, politics, culture, and education. in educational context, this situation can be benefitted in educational activities by instilling the Islamic values in all lesson.

The integration of Islam in all lessons, including foreign language, is important to do because Muslim teachers also have a role in preserving the religious values through their classroom activities. Also, the linguistic reasons suggest the teachers execute this efforts in their classrooms as what Johnston (2003) said that, like the essence of all teaching, the essence of language teaching lies in values. It means that, when FL instruction is instilled with religious values, the pedagogic goal of FL teaching will keep being reached.

Related to the integration of Islamic values into FL teaching, Mahboob (2009) has proposed a framework that can be used to study the relationship between local Islamic values and the English language in other contexts. Meaning to say, Islamic values and local culture can be instilled in the teaching of foreign language, like English. It is known that language is closely related to culture and according to Fuller and Wardhaugh, as cited by Rangriz and Harati (2017), one of the relationships of language and culture is that social structure may either affect or decide linguistic structure and/or behavior.

To sum up, Indonesian Muslims teaching a foreign language need to organize the instructional activities promoting Islamic values. From the abovementioned scholarly statements, it can be inferred that Muslim teachers who teach a foreign language should consider integrating the Islamic values into their teachings to accommodate the Islamic values in their lessons. This is a review paper aimed at discussing the debates on the importance of value integration into instruction, the strategies of instilling the Islamic values into the teaching of foreign language, and best practices that have been done by some teachers.

\section{ARGUMENTS ON THE TEACHING OF VALUES}

The rise of problems in Indonesia such as violence, intolerance, bad habit, corruption and so forth insists all people in education fields take a part in decreasing these problems by implementing, among others, value education into their instruction. Veugelers \& Vedder (2003) maintain that the concept 'value education' refers to teaching of good values in any aspects such as social, political, cultural, and aesthetic values. These values are covered in religion because it is where everything is ruled. Value education, according to Deveci (2015), should be methodically executed through highly structured plans in order to set the social order in which people have obtained a variety of values.

What is value? A wide range of scholarly writings tries to give exact definitions on it. Although sometimes ambiguous, efforts have been made to give clear definition. Schwartz and Bilsky as cited by Van der Weide et al (2009) proposed a consensus on five common features of values: values are (a) concepts or beliefs, (b) about desirable end states or behaviors, (c) that transcend specific situations, (d) guide selection or evaluation of behavior and events, and (e) are ordered by relative importance.

The next thing to ask is what are so-called Islamic values? According to Akgunduz (2010), Islamic values are the series of life principles on how human should live it. They are divided into three levels namely (1) necessities (dharuriyyat); (2) convenience (hajiat); and (3) refinements (kamaliat). In the legal theory (usul al-fiqh) of Islam, there is a maxim "the general aim of legislation" in Islam is to realize values through protecting and guaranteeing their necessities (aldharuriyyat) as well as fulfilling their importance (al-hajiyyat) and their embellishments (tahsiniyyat). The human basic values consist of life (al-nafs), reason (al-'aql), descent (nasab), property (al-mal) and religion (al-din). Islam protects these primary human values, and prohibits any violation of them.

What is actually the role of the teaching of values? Sanchez (2005) stated that the teaching of value becomes the basis for citizenship and the maintenance of the democratic nation. Then how to do the teaching of values? According to Ling and Stephenson, as cited by Irwansyah (2016), there are at least three paradigms underpinning the strategies of the teaching of values.

\subsection{Religious monopolism}

Values are taught within the framework of religion. This paradigm seems inappropriate for heterogonous learners in terms of religion. This paradigm is applicable for religion-based institutional context such Islamic schools (e.g.: MI, SDIT, MTs, MA, STAIN, IAIN and UIN), Christian schools (e.g., SD, SMP, and SMA Xaverius; Christian Universities) and other religion-based 
schools. To illustrate this point, a headmaster of a Madrasah Ibtidaiyah (Islamic Elementary School) make a policy of performing dhuha prayer obligated by all teachers in students at the school everyday. This religious value is monopolized since all people in the school are homogenonous, Muslims.

\subsection{Moral universalism}

Teaching universal moral principles which are considered general for all religions. Here, it is teaching common and universal meanings and understanding. This paradigm is appropriate for general schools both private and state institutions in Indonesia such as SDN, SMPN, SMAN, PTN and so forth. For example, a state university affirms the value of tolerance by enrolling the students from diverse ethnicity, religion and social status.

\subsection{Consensus pluralism}

The values and principles to be taught in the school are obtained through consensus and negotiation. This paradigm is mainly adapted to maintain a secular, democratic and pluralistic school. This paradigm might not applicable for Indonesian context since religion, as opposed to the secular idea, plays a fundamental part of the country's policies on education.

The teaching of values, as stated by Harecker (2012), is to implement the fact that teaching is not only understood as education organized in schools in the sense of an wide-ranging help for enculturization, but it also covers educational aids which are not only intended for escalating knowledge and ability but also at obtaining norms and values.

\section{HOW AND WHAT TO INSTILL ISLAMIC VALUES IN FL INSTRUCTION?}

In Indonesia there are some foreign languages commonly learned, such as English, Arabic, Mandarin and currently Korean language. From these foreign languages, the most easily conducted integration of Islamic values in the instruction is the Arabic language. As commonly known, Arabic is the command of Islamic religion, because it is the original language of Al-Qur'an. Thus, as said by Mat and Wan Abas, (2016, p. 206) it is considered by many Muslim scholars that mastering the Arabic language is a requirement to gain comprehensive learning and understanding of Islam. In other words, instilling Islamic values in the Arabic language teaching is not a big challenge. But, what about the other foreign languages such as English, Mandarin, Spanish and so on?

make the integration of Islamic values in FL instruction applicable, some researchers have done some studies and practices. From them, it is found some practical ways to do this integration as follows:

\subsection{Curriculum}

A study by Shah, Muhamad and Ismail (2012) shows that design, implementation and execution of an English language curriculum from an Islamic perspective is greatly feasible if an educational institution is willing to deal with detailed prerequisites, determine existing challenges and declare the superiority of an Islamic model of education grounded in Tawhid.

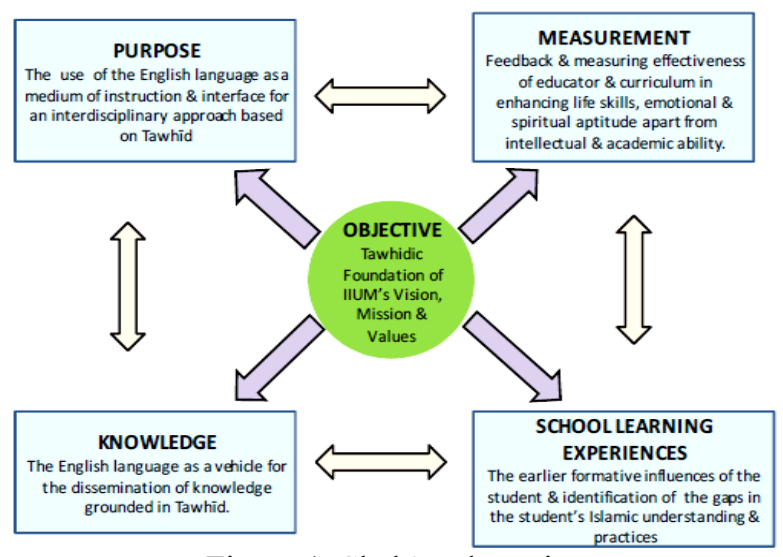

Figure 1. Shah's adaptation

of Kerr's curriculum development model

By adapting this western model, they show that secular models can be Islamized and contribute to the development of an Islamic English language curriculum. The figure shows that the aspects of curriculum with Islamic messages are broken down from the vision and mission of the Islamic institutions. It can be inferred that if the schools are not Islam-based, teachers are probably not encouraged to instill Islamic values.

\subsection{Learning materials}

Zuliati Rohmah (2012) offered learning materials to be added to the Islamic messages in language teaching. One of the available course books is 
"English in Context" trainers under the Islamic Schools English Language Project (ISELP). This book is used by the teachers in pesantren. In this book, the Islamic messages are included by two ways: 1) directly mentioning Islamic topics like "How to wudhu", "Muslim to Muslim" and so forth. 2) incorporating the Islamic messages in the materials indirectly through pictures, names, building, language activities, messages, etc.

In pursuit of finding the Islamic values instilled in English textbooks, Al Qomoul (2015) analyzed all the English language books for the first three basic grades in Jordan. The selected values are necessary for the accomplishment of goals and behaviors of learning, both in general lesson and in learning English as a foreign language. Then, Umam (2014) revealed that the integration of Islamic values in Indonesian pesantrens could be done by using the existing textbooks containing Islamic values. Referring to this research, there are some books; one of them is "English for Muslim Learners" written by Irwansyah (2015).

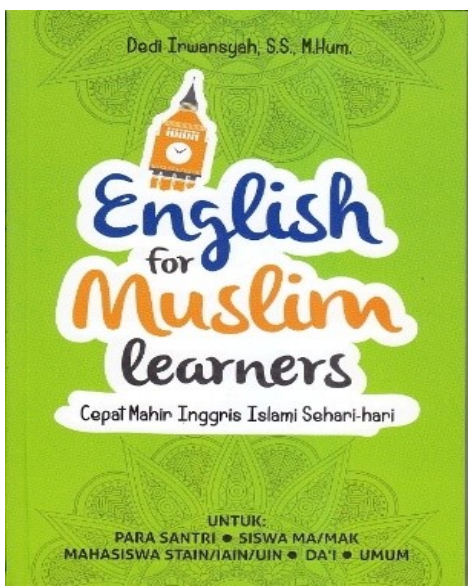

Figure 2. An English textbook full of Qur'an and Hadith messages (Irwansyah, 2015)

The other alternative was using value-based authentic materials. Today it is easy to take authentic materials from newspapers, TV programs, menus, magazines, the internet, movies, songs, brochures, comics, literature (novels, poems and short stories), and many others. The following is an example of a free access website containing a number of Islamic stories. It really eases the teachers to find materials containing Islamic messages.

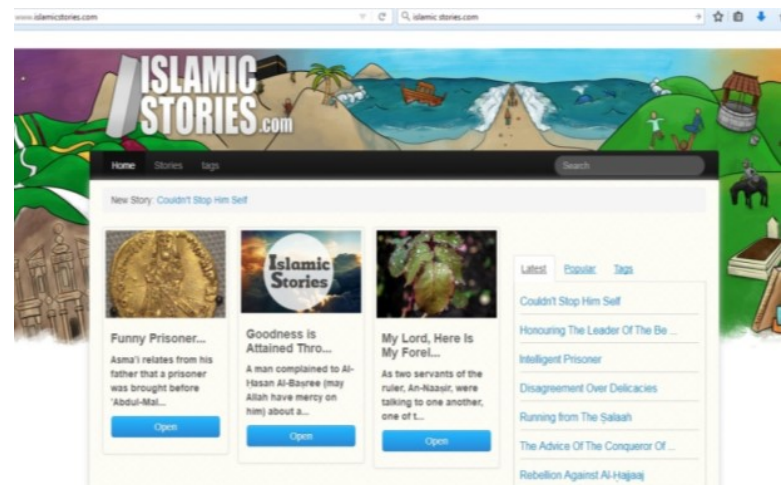

Figure 3. An Islamic stories-based website

In the context of today's 21 st learning, using this kind of ICT-based media is highly recommended (Shyamlee \& Phil, 2012) since the learners, socalled digital natives, are very familiar with technological devices. Since it is also easy to get the materials containing Islamic values from the internet, the teachers should consider using this for teaching foreign languages with Islamic values in a fun way.

\subsection{Instructional activities}

Based on Khamdan's study, in the instructional activities, the integration of the Islamic values, was done in four ways i.e. (1) by performing codemixing and code-switching between English and the Islamic expressions based on the situational context; (2) by relating the topic discussed to the relevant Islamic teaching which is done either by quoting the verses of Al-Qur'an and/or Al-Hadith, or by explaining the relevant Islamic teaching; (3) by using the Islamic names for persons like Ahmad instead of John, places like Mecca, or events in making the example of sentences or dialog script; (4) by giving students assignment to write or find a kind of text related to the Islamic values relevant to the topic discussed.

Meanwhile, according to Notman, et al (2011) the three most preferential strategies for teaching values were teacher role modeling, making effective use of the "teachable moment", and clear teaching of a particular value through role plays and dramatic presentations. This is because the values are existed at the heart of each teacher's individuality ego, practically creating his axiological profile (Cojocariu, 2015).

The value education is similar to character education that can be integrated in foreign language teaching. The integration, as elaborated by Albantani \& Madkur (2016), can be implemented through: (1) 
accommodating the character values with the lesson, (2) instilling character values in every learning activity, (3) delivering the character values through teaching method used, and (4) planting and practicing character education values through everyday life.

\section{BEST PRACTICES}

Even though hard to do, there have been some foreign language teachers implementing the integration of Islamic values in foreign language teaching. To first mention, English language teaching in SMP Islam Al-Azhar 15 Cilacap. As reported by NurKhamdan (2008), the Islamic values in the lesson plans were integrated in the section of the instructional materials and in the instructional activities of the lesson plans. In the section of the instructional materials of the lesson plans, the integration was done by embedding the Islamic values supported by verses of Al-Qur'an and/or AlHadith which are relevant to the main materials selected based on predetermined instructional objectives.

The other practice was the teaching of English language in SMA Negeri Banjarbaru. The results of this study found that all English teachers in this school already integrate the values of existing characters in English learning that is honest, responsibility, discipline, cooperation, hard work, curiosity, likes to read. Teaching is done with various methods of variation in every meeting, the method used is the method of discussion, demonstration, lecture and question and answer. With the existence of Islamic character values that have been integrated into every subject in school, especially in English lesson then it is expected that students can apply the values of Islamic character in daily life (Irveanty, 2013).

The third practice was the use of Islamic magazine in teaching reading comprehension for the students of English Education Department of IAIN Batusangkar. Because of more colorful, made with quality papers, layout attractiveness, and accessible by the students, the magazine was motivating. After being this researched, this teaching strategy prove that the articles in the Islamic magazine empirically enhanced the students reading comprehension and built their character values (Munir \& Hartono, 2016).

\section{WHAT ARE THE CHALLENGES?}

Instilling Islamic values in foreign language teaching which can be included in the term "value education" always has some challenges.

\subsection{The teacher's qualification}

Teachers are role models for their students. Therefore, when teaching they should share their good character (Lumpkin, 2008). One of the reasons why Muslim teachers should instill Islamic values while teaching is because there must be a different method and materials when teaching Muslim students. In other words, an English teacher in Madrasah Aliyah, differing from general or nonIslamic schools, should be able to creatively integrate Islamic values so that the Muslim students feel familiar with the content of material and in the same time develop their ability in foreign language. This is challenging since not all teachers can do due to the fact that not all Muslim teachers have such a good knowledge on Islam and know how to effectively deliver it in instructional activities. Hence, it is very important for the decision makers in schools to pay big attention to this issue when they are hiring a new teacher.

\subsection{What values should be taught?}

Islam covers everything in human's life; and therefore it is challenging the teacher to see what kind of Islamic values that they should teach to their students. This is task of the teachers and stakeholders at schools to decide since it is impossible to integrate all Islamic values in the instruction. In Indonesian context, especially 2013 curriculum, it is suggested to calculate 18 character education values in all of subjects including foreign language taught to the students (Nur \& Madkur, 2014). These 18 character values are of course covered in Islam. In addition, teachers can match the values with the vision and mission of the schools.

\subsection{When to teach Islamic values in classroom?}

Some teachers are questioning when the values should be taught. Since the teaching and learning process in the classroom consists of pre-teaching, while-teaching and post-teaching, the teachers sometimes get difficulties to allocate time to teach the Islamic values. They are willing to teach the values but, at the same time, they are worried of 
overlapping the learning materials. In this case, Veugelers \& Vedder (2003) prefer to apply integrated approach by which the teachers both stimulate certain values and teaching language skills to better communicate on values, and increase the active participation of students. However, using this approach, some teachers get confused in what part of instruction they should instill the Islamic values.

\section{CONCLUSIONS}

Embracing the religiousity in FL instruction is theoretically and practically recognized. In Indonesian context, the teaching of foreign language needs to execute the instilling of religious values. Based on the discussion of this study, there are some recommendations to be useful considerations for us, the writers, and foreign language teachers, especially who teach in Islamic schools, to instill the Islamic values. The schools need to supply the textbooks with more Islamic values, especially, those related to faith, worship and morals to help building up and developing the Muslim youths' personality so that the teachers can have a kind of guidance in a classroom. The schools should support and motivate the teachers to instill Islamic values into their subjects. The values should be recognized by delivering tips that would help students to think of the current world issues positively and preparing them for creativity. The values should be presented in different ways in the style of description, modeling and then demonstration. For those teachers who do not yet have sufficient knowledge about Islam, more learning should be done.

\section{REFERENCES}

Akgunduz, A. (2010). The values and norms of Islam. The Journal of Rotterdam Islamic and Social Sciences, 1(1), pp. 1-20.

Albantani, A., M. (2016). Integrating character education values in language teaching: Why and how? The Fourth ELITE International Conference Proceeding. Jakarta: UIN Jakarta.

Aldashev, G. \& Platteau, J. (2014). Religion, culture, and development. Handbook of the Economics of Art and Culture, 2, p.590.

Al.Qomoul, M. D. S. (2015). The Islamic values implemented in the English language syllabuses for the first three grades in Jordan. European Journal of Language, Linguistics and Literature, 3(1), 15-29.

Atay, D. et.al (2009). The role of intercultural competence in foreign language teaching. Inonu
University Journal of the Faculty of Education, 10(3), pp. 123-135.

Bagaric, V. (2007). Defining communicative competence. Metodika, 8(1), pp. 94-103.

Buttjes, D. (1990). Teaching foreign language and culture: social impact and political significance. Language Teaching Journal, 2, 53-57.

Cojocariu, M., V. (2015). Anchor-values of the axiological universe of primary teachers. Procedia- Social and Behavioral Sciences 180, pp. 524-530.

Deveci, H. (2015). Value education through distance learning: Opinions of students who already completed value education. Turkish Online Journal of Distance Education, 16(1), pp. 112126.

Foye, K. (2004). Religion in the ELT classroom: Teachers' perspectives. The Language Teacher, $38(2)$.

Harecker, G. (2012). Teaching Values at School: a Way to Reach a Better Understanding in Our World, in Conference Proceedings New perspectives in Science Education, Florence, Italy: Pixel, University Press.

Irveanty, Mar'idveanita (2013) Integrasi Nilai-Nilai Karakter Islami dalam Pembelajaran Bahasa Inggris di SMAN Banjarbaru. Unpublished Thesis, IAIN Antasari.

Irwansyah, D. (2015). English for Muslim Learners. Yogyakarta: Kalarana Press.

Irwansyah, D. (2016). Integrating values into literature-based learning materials. Proceeding of Consortium of Linguistics and Literature. Adab Press: Faculty of Adab and Cultural Sciences. UIN Sunan Kalijaga, pp. 153-161.

Johnston, B. (2003). Values in English language teaching. Mahwah, NJ: Lawrence Erlbaum Associates.

Khamdan, N. (2008). The integration of teaching of English with the Islamic values at SMP Islam Al-Azhar 15 Cilacap. Unpublished Thesis. State Univesity of Malang.

Kilp, A. (2011). Religion in the construction of the cultural 'self' and 'other'. ENDC Proceedings, 14, pp. 197-222.

Liyanage, I., Bartlett, B., \& Grimbeek, P. (2010). Religious background and language learning: Practical suggestions for deriving best practice in ELT. Asian EFL Journal, 46, 28-47.

Lumpkin, A. (2008). Teachers as Role Models teaching character and moral virtues. JOPLRD, 79(2), pp. 45-49.

Mahboob, A. (2009). English as an Islamic language: a case study of Pakistani English. World Englishes, 28(2), pp. 175-189.

Mat, H and Wan Abas, U., M., W. (2016). The relevance of Arabic language in Islamic studies 
program: A case study of Open University Malaysia (OUM). Journal of Education and Social Sciences, 5(2), pp. 205-209.

Mecham, M., T. (2012). Exploring second language learning: communicative competence, pragmatics, and second language literacy. All Graduate Plan B and other Reports, 166.

Mitchell, J., P., Pardinho, A., L., YermakovaAguiar, N., Meshkov, V., L. (2015). Language learning and intercultural communicative competence: An action research case study of learners of Portuguese. Procedia - Social and Behavioral Sciences, 200, pp. 307-312.

Munir, S. \& Hartono R. (2016). Islamic magazine articles to enhance students' reading skill and build their character values. International Journal of Education, 9(1), pp. 68-73. doi: dx.doi.org/10.17509/ije.v9i1.3720.

Notman., et.al. (2011). Integrating values in the New Zealand Curriculum: Caught or taught? Teaching and Learning Research Initiative, pp. $1-7$.

Nur, R.M., \& Madkur, A. (2014).Teachers' voices on the 2013 curriculum for English instructional activities. Indonesian Journal of English Education, 1(2), pp. 119-134.

Purgason, K. (2009). Classroom guidelines for teachers with convictions. In M. Wong \& $\mathrm{S}$. Canagarajah (Eds.), Christian and critical English language educators in dialogue: Pedagogical and ethical dilemmas (pp. 185192). New York: Routledge

Qu, Yi. (2010). Culture understanding in foreign language teaching. English Language Teaching, 3(4), pp. 58-61.

Rangriz, S. \& Harati, M. (2017). The relationship between language and culture. Journal of applied Linguistics and Language Research. 4(6), pp. 209-213.

Rohmah, Z. (2012). Incorporating Islamic messages in the English teaching in Indonesian context. International Journal of Social, Science, and Education, 2(2), pp. 157-165.

Sanchez,R., T. (2005). Facing the challenge of character education. Available at files.eric.ed.gov/fulltext/EJ718739.pdf

Sasaki, Y., J. \& Kim, S., H. (2011). At the Intersection of culture and religion: A cultural analysis of religion's implications for secondary control and social affiliation. Journal of Personality and Social Psychology, 101(2), pp. 401-414.

Shahjahan, R. A. (2004). Centering spirituality in the academy: Toward a transformative way of teaching and learning. Journal of Transformative Education, 2(4), pp. 294-312. doi: $10.1177 / 1541344604268330$
Shahjahan, R. A. (2010). Toward a spiritual praxis: The role of spirituality among faculty of color teaching for social justice. The Review of Higher Education, 33(4), pp. 473-512. doi: 10.1353/rhe. 0.0166

Shah, M.I.A., Muhamad, A.J., \& Ismail, S.M. (2012). Design, formulation and implementation of an English language curriculum from Islamic perspective. Journal of Islam, 9(2).

Shyamlee, S.D. (2012).Use of Technology in English Language Teaching and Learning": An Analysis. International Conference on Language Proceeding, Medias and Culture, pp. $150-156$

Umam, C. (2014) Maintaining Islamic values in English language teaching in Indonesian pesantrens. Didaktika Religia, 2(1), pp.227242.

Van der Weide, T.L., Dignum, F., Meyer, J.-J.C., Prakken, H., Vreeswijk, G.A.W. (2009). Practical reasoning using values. In McBurney, P., Rahwan, I., Parsons, S., Maudet, N. (eds.) ArgMAS 2009. LNCS, 6057, pp. 7993. Springer, Heidelberg.

Veugelers, W. \& Vedder, P. (2003). Values in teaching. Teachers and Teaching: theory and practice, 9(4), pp. 377-389.

Wahyudi, R. (2012). Intercultural languages education and its complex insights: the case of Indonesian Islamic higher education. Theory and Practice in Language Studies, 2(9), pp. 1783-1791.

Wicking, P. (2012). God in the classroom. The Language Teacher, 36(5), pp. 35-38. 